\title{
STABILITY INDICATING RP-HPLC ASSAY METHOD FOR ESTIMATION OF DIMETHYL FUMARATE IN BULK AND CAPSULES
}

\author{
HEMANT K. JAIN*, ARCHANA A. GUNJAL \\ Department of Quality Assurance Techniques, Sinhgad College of Pharmacy, Vadgaon (Bk.), Pune (411041), Maharashtra, India \\ Email: hemantkjain2001@yahoo.co.in
}

Received: 25 Jun 2017, Revised and Accepted: 22 Aug 2017

\section{ABSTRACT}

Objective: To develop an accurate, simple, precise and specific stability indicating RP-HPLC method for estimation of dimethyl fumarate in bulk and capsules.

Methods: An Inertsil ODS $(150 \times 4.6 \mathrm{~mm}, 5 \mu)$ column and a mobile phase containing acetonitrile: potassium dihydrogen phosphate buffer pH 6.8 $(50: 50 \% \mathrm{v} / \mathrm{v})$ was used for this study. The flow rate was maintained at $1.0 \mathrm{ml} / \mathrm{min}$; column temperature was fixed at $35{ }^{\circ} \mathrm{C}$ and $\mathrm{UV}$ detection was carried out at $210 \mathrm{~nm}$. The forced degradation studies were performed and method was validated with as per ICH guidelines.

Results: The retention time of dimethyl fumarate was found to be $3.3 \pm 0.02 \mathrm{~min}$. The value of correlation coefficient between peak area and concentration was found to be 0.9993 . The mean percent recovery of dimethyl fumarate in capsules was found in the range of 99.65 to $101.64 \%$. The results of forced degradation studies indicated that the drug was found to be stable in basic, oxidative and thermal conditions while degraded in acidic conditions.

Conclusion: It can be conducted from results that the developed HPLC method is simple, accurate, precise and specific. Results of stress testing study revealed that the method is stability indicating. Thus, this method can be used for routine analysis of dimethyl fumarate capsules and check their stability.

Keywords: Dimethyl fumarate, RP-HPLC, Method validation, Stability indicating assay method

(C) 2017 The Authors. Published by Innovare Academic Sciences Pvt Ltd. This is an open access article under the CC BY license (http://creativecommons.org/licenses/by/4.0/) DOI: http://dx.doi.org/10.22159/ijap.2017v9i5.20944

\section{INTRODUCTION}

Dimethyl fumarate is an anti-inflammatory drug, which is chemically trans-Butenedioic acid dimethyl ester [1]. The US FDA approved Tecfidera capsules (containing $240 \mathrm{mg}$ of dimethyl fumarate) on March 27, 2013. This drug is indicated for the treatment of a patient with relapsing forms of multiple sclerosis [2]. Dimethyl fumarate is not an official drug in any Pharmacopoeia. Literature survey revealed that some methods have been reported for the determination of dimethyl fumarate by HPLC [3-6] and hyphenated techniques such as LC-MS [7], either alone or in combination. However, there is no stability indicating HPLC assay method was reported yet for estimation of dimethyl fumarate in capsules. This paper presents a simple stability indicating RP-HPLC assay method for estimation of dimethyl fumarate in bulk and capsules that can be used in stability testing.<smiles>COC(=O)/C=C/C(=O)OC</smiles>

Fig. 1: Chemical structure of dimethyl fumarate

\section{MATERIALS AND METHODS}

\section{Chemicals and reagents}

Dimethyl Fumarate API was procured from Enaltec Research Centre, Ambernath, India as a gift sample. Capsules (containing $240 \mathrm{mg}$ of dimethyl fumarate) were obtained in a house in Enaltec Research Centre. Methanol, Acetonitrile was obtained from Rankem Pvt. Ltd, Mumbai and Perchloric acid was obtained from Merck Specialties Pvt. Ltd, Mumbai.

\section{Instruments}

The method was performed on Shimadzu LC-2010C HT HPLC system with automatic injection facility and UV-Visible detection system. Analytical Balance Mettler Toledo XS205 and Column Symmetry Shield Inertsil ODS ( $150 \times 4.6 \mathrm{~mm}, 5 \mu)$ were used for this study.

\section{Preparation of standard stock solution}

$100 \mathrm{mg}$ of dimethyl fumarate was accurately weighed and transferred into a $100 \mathrm{ml}$ volumetric flask. This drug was dissolved with $30 \mathrm{ml}$ of methanol and sonicated for $15 \mathrm{~min}$. Then this solution was diluted up to the mark with a diluent (Acetonitrile: buffer PH $6.850: 50 \% \mathrm{v} / \mathrm{v}$ ) this solution was further diluted 10 times with the same diluent.

\section{Assay of capsules}

The content of twenty capsules was weighed and an average weight of a capsule was calculated. An accurately weighed amount of powder equivalent to $100 \mathrm{mg}$ of drug was transferred to a $100 \mathrm{ml}$ volumetric flask and $30 \mathrm{ml}$ of methanol was added to it. Then the mixture was sonicated for 15 min and diluted up to mark with the diluent. This solution was further diluted to obtain about $100 \mu \mathrm{g} / \mathrm{ml}$ solutions with the same diluent and filtered through $0.45 \mu$ nylon membrane syringe filter before injection. This procedure was repeated in triplicate. The results of the assay of capsules are shown in table 2.

\section{Validation of the method}

The developed chromatographic method was validated for linearity, range, accuracy, precision, robustness and specificity parameters, as per ICH guidelines [8].

\section{Linearity and range}

Working standard solutions were injected under the optimized chromatographic conditions and peak areas were calculated at 210 nm. A calibration curve was plotted between areas against corresponding concentrations of the drug. Linear regression data for calibration curve was shown in fig. 3 . The range of solution has been decided according to Karl Pearson's correlation coefficient.

\section{Precision}

Repeatability study was carried out with six replicates and intermediate precision studies were carried out with three concentrations of dimethyl fumarate with three replicates. The values of \% relative standard deviation (\% RSD) of precision study are shown in table 3. 


\section{Accuracy}

The accuracy of the method was determined by calculating percent recovery of the drug by standard addition method. Percent recovery of dimethyl fumarate was determined at three different levels 50,100 and $150 \%$ of the target concentration in triplicate. The results of accuracy study are shown in table 4 .

\section{Robustness}

Robustness of the optimized method was studied by changing flow rate $( \pm 0.2 \mathrm{ml} / \mathrm{min})$, change in wavelength $( \pm 2 \mathrm{~nm})$ and change in mobile phase composition $( \pm 5 \%)$ during analysis. The sample was injected in triplicate for every condition and cumulative \% RSD was calculated for each condition is shown in table 5 .

\section{Specificity}

Blank (diluent), standard, sample and identification solutions (spiked with a fumaric acid and monomethyl fumarate impurities) were injected to HPLC. The results (retention time, purity angle and purity threshold) obtained by this study is summarized in table 6 . The chromatograms obtained by this study are presented in fig. 4(a), (b) and (c).

\section{Forced degradation studies}

To evaluate stability, dimethyl fumarate was subjected to force degradation conditions (acid, base, neutral hydrolysis and oxidation as well as heat) as per international conference on harmonization (ICH) guidelines [9-12].

No treatment sample was prepared similarly as assay procedure for capsules. The chromatogram of no treatment sample is presented in fig. 5(a).

\section{Acid hydrolysis}

An accurately weighed amount of capsule's powder equivalent to $100 \mathrm{mg}$ of dimethyl fumarate was transferred to a $100 \mathrm{ml}$ volumetric flask. Then $5 \mathrm{ml}$ of $0.1 \mathrm{~N} \mathrm{HCl}$ was added and refluxed at $80^{\circ} \mathrm{C}$ for $1 \mathrm{~h}$ [13]. This solution was neutralized by adding $5 \mathrm{ml}$ of $0.1 \mathrm{~N} \mathrm{NaOH}$. Methanol $(30 \mathrm{ml})$ was added to this mixture and sonicated for $15 \mathrm{~min}$.

Then volume was made up to the mark with diluent. The resultant solution was further diluted, filtered and analyzed using HPLC. The chromatogram obtained by acid hydrolysis is given in fig. 5(b).

\section{Alkaline hydrolysis}

An accurately weighed amount of capsule's powder equivalent to $100 \mathrm{mg}$ of dimethyl fumarate was transferred to a $100 \mathrm{ml}$ volumetric flask. Then $5 \mathrm{ml}$ of $0.1 \mathrm{~N} \mathrm{NaOH}$ was added and refluxed at $80{ }^{\circ} \mathrm{C}$ for $1 \mathrm{~h} \mathrm{[14]}$. This solution was neutralized by adding $5 \mathrm{ml}$ of $0.1 \mathrm{~N} \mathrm{HCl}$. Methanol $(30 \mathrm{ml})$ was added to this mixture and sonicated for $15 \mathrm{~min}$. Then volume makeup, further dilution, filtration and analysis was done similar to acid hydrolysis. The chromatogram obtained by alkaline hydrolysis is given in fig. 5(c).

\section{Oxidative degradation}

An accurately weighed amount of capsule's powder equivalent to $100 \mathrm{mg}$ of dimethyl fumarate was transferred to a $100 \mathrm{ml}$ volumetric flask. Then $5 \mathrm{ml}$ of $3 \% \mathrm{H}_{2} \mathrm{O}_{2}$ was added and refluxed at $80^{\circ} \mathrm{C}$ for $1 \mathrm{~h}$. Methanol $(30 \mathrm{ml})$ was added to this mixture and sonicated for 15 min. Then volume makeup, further dilution, filtration and analysis were done similar to acid hydrolysis. The chromatogram obtained by oxidative degradation is given in fig. 5 (d).

\section{Thermal degradation}

An accurately weighed amount of powder equivalent to $100 \mathrm{mg}$ of drug was taken and kept in oven for $1 \mathrm{~h} 105^{\circ} \mathrm{C}$. Sample was transferred to $100 \mathrm{ml}$ volumetric flask and $30 \mathrm{ml}$ of methanol was added to it. Then the mixture was sonicated for $15 \mathrm{~min}$. the sample was allowed to cool at room temperature. Then volume make up, further dilution, filtration and analysis was done similar to acid hydrolysis. The chromatogram obtained by thermal degradation is given in fig. 5(e).

\section{Stability of analytical solutions}

The standard and sample solutions were kept at bench top and in stability chamber at $15^{\circ} \mathrm{C}$ for $46 \mathrm{~h}$ and injected from time to time on to the HPLC. The data obtained are summarized in table 7.

\section{Filter compatibility study}

Unfiltered and filtered standard solutions (by PVDF, Nylon, and PTFE) were injected to HPLC system. Sample solutions were centrifuged at $5000 \mathrm{rpm}$ for $10 \mathrm{~min}$, filtered similarly as standard solutions and injected to the HPLC system. The data obtained by this study is summarized in table 8.

\section{RESULTS AND DISCUSSION}

\section{Optimization of chromatographic conditions}

UV spectrum of dimethyl fumarate showed the maximum absorbance of the drug was found at $210 \mathrm{~nm}$. Hence, $210 \mathrm{~nm}$ wavelength was selected for UV detection. Initially, various chromatographic conditions were tried in order to obtain better separation characteristics, by changing the composition of different mobile phases. Finally, mobile phase consists of acetonitrile: potassium dihydrogen phosphate buffer $\mathrm{pH} 6.8(50: 50 \% \mathrm{v} / \mathrm{v})$ was selected at a flow rate of $1.0 \mathrm{ml} / \mathrm{min}$ and UV detection $(210 \mathrm{~nm})$. The value of retention time of drug was found to be $3.46 \mathrm{~min}$, indicated that the method is rapid. The chromatogram of dimethyl fumarate is shown in fig. 2. The optimized chromatographic conditions and system suitability parameters are mentioned in table 1.

\section{Assay of capsules formulation}

The value of mean \% drug in the capsules was found to be $100.1 \%$ (table 2), which was within acceptance criteria.

\section{Precision}

The method is precise and the \% RSD values were within an acceptable limit.

Table 1: Optimized chromatographic conditions and system suitability parameters

\begin{tabular}{ll}
\hline Parameters & Details \\
\hline Mobile phase & Acetonitrile: Potassium dihydrogen phosphate buffer $\mathrm{pH} 6.8(50: 50 \% \mathrm{v} / \mathrm{v})$ \\
Column & GL Science, Inertsil ODS, $150 \times 4.6 \mathrm{~mm}, 5 \mu$. \\
Flow rate & $1.0 \mathrm{ml} / \mathrm{min}$ \\
Detection & $210 \mathrm{~nm}$ \\
Injection volume & $5 \mu \mathrm{l}$ \\
Run time & $7 \mathrm{~min}$ \\
Retention time & $3.3+0.02 \mathrm{~min}$ \\
Diluent & Acetonitrile: (Potassium dihydrogen phosphate) buffer Ph $6.8(50: 50 \% \mathrm{v} / \mathrm{v})$ \\
Tailing factor & 1.25 \\
Theoretical plates & 5857 \\
\hline
\end{tabular}




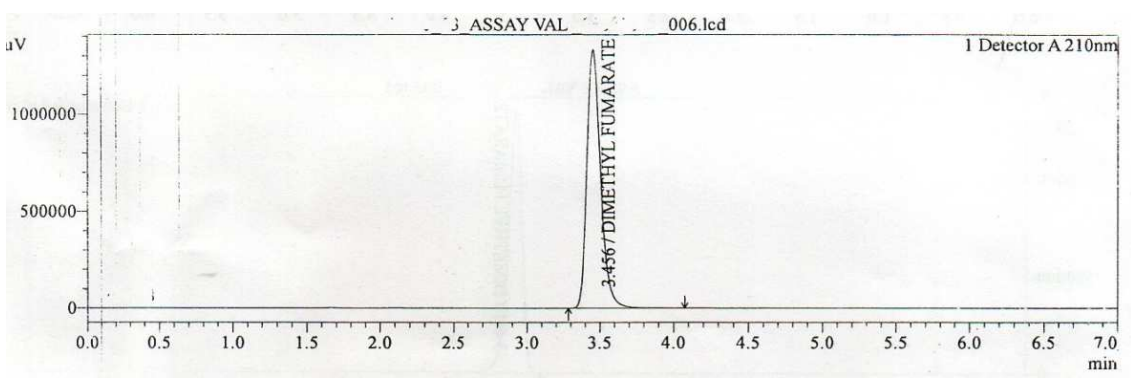

Fig. 2: Chromatogram of dimethyl fumarate

Table 2: Results of assay of dimethyl fumarate

\begin{tabular}{llll}
\hline S. No. & Sample solution concentration $(\boldsymbol{\mu g} / \mathbf{m l})$ & Area & Amount of drug estimated mean $\pm \%$ RSD $^{*}$ \\
\hline 1 & 100 & 8549821 & \\
2 & 100 & 8569754 & $100.1 \pm 0.12$ \\
3 & 100 & 8567736 & \\
\hline
\end{tabular}

${ }^{*}$ The value is represented as a mean $\pm \% \mathrm{RSD}$ of 3 observations.

Table 3: Repeatability and intermediate precision for dimethyl fumarate

\begin{tabular}{|c|c|c|c|}
\hline Precision & Concentration of drug $(\mu \mathrm{g} / \mathrm{ml})$ & Mean area \pm SD* & \% RSD \\
\hline Repeatability $(\mathrm{n}=6)$ & 100 & $8705641 \pm 68889$ & 0.82 \\
\hline \multirow[t]{3}{*}{ Intra-day $(n=3)$} & 75 & $6377573.3 \pm 9957$ & 1.57 \\
\hline & 100 & $8329129.3 \pm 7385$ & 0.88 \\
\hline & 125 & $108269176 \pm 3335$ & 0.30 \\
\hline \multirow[t]{3}{*}{ Inter-day $(\mathrm{n}=3)$} & 75 & $6377573.3 \pm 15357$ & 0.24 \\
\hline & 100 & $8368268.3 \pm 168167$ & 2.00 \\
\hline & 125 & $10979590.3 \pm 592188$ & 0.5 \\
\hline
\end{tabular}

*Each value is represented as a mean \pm SD of n observations. SD: standard deviation, \%RSD: Percent relative standard deviation.

\section{Accuracy}

The values of percent recovery of the developed method (table 4) were found in acceptance criteria. Results of accuracy studies of the method were found satisfactory as the average mean $\%$ recovery \pm RSD was $100.5 \pm 0.56 \%$. Therefore, this method is accurate.

\section{Linearity and range}

The value of correlation coefficient for dimethyl fumarate (fig. 3) demonstrated the good relationship between peak areas and concentrations. Therefore, the developed method was found to be linear in the concentration range of $25-150 \mu \mathrm{g} / \mathrm{ml}$.

Table 4: Recovery study for dimethyl fumarate

\begin{tabular}{llll}
\hline Level \% & Amount taken $(\mu \mathrm{g} / \mathbf{m l})$ & \% recovery* & Mean \% recovery \pm RSD \\
\hline 50 & \multirow{2}{*}{15} & 99.87 & $100.5 \pm 0.63$ \\
& & 102.00 & $99.65 \pm 0.36$ \\
100 & 20 & 98.28 & $101.64 \pm 0.70$ \\
& & 99.40 & 100.07 \\
\end{tabular}

*Percent recovery was in triplicate, \% recovery: Percent recovery, \%RSD: Percent relative standard deviation.

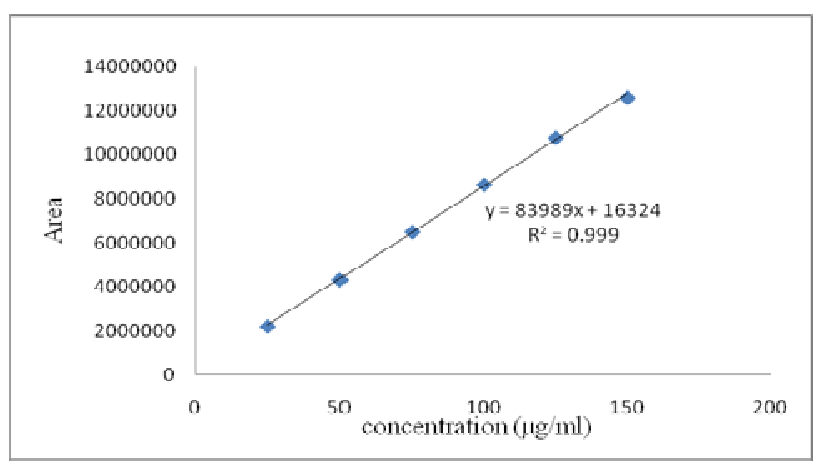

Fig. 3: Calibration curve of dimethyl fumarate 


\section{Robustness}

The value of \% RSD was found to be within acceptance criteria which showed the reliability of the method.

\section{Specificity}

The results of specificity study are shown in fig. 4 (a), (b) and (c). The obtained chromatograms showed that there no interfering peak was observed of blank, sample and standard solution at the retention time of dimethyl fumarate. Purity angle was observed that less than purity threshold for all peak observed. The value of retention time of dimethyl fumarate for standard solution and sample was same, however, the retention time of expected components was observed at different values. All these parameters indicated the specificity of the method.

\section{Forced degradation studies}

Chromatograms obtained under different stress conditions like acidic, alkaline hydrolysis, oxidative, thermal degradation are presented in fig no. 5(a), 5(b), 5(c), 5(d) and 5(e).

Table 5: Robustness study for dimethyl fumarate

\begin{tabular}{lc}
\hline Parameters & \% RSD \\
\hline A: Change in flow rate $\mathbf{( \pm 0 . 2 ~} \mathbf{~ m l} / \mathbf{m i n})$ & $0.13 \%$ \\
$0.8 \mathrm{ml} / \mathrm{min}$ & $0.11 \%$ \\
$1 \mathrm{ml} / \mathrm{min}$ & $0.19 \%$ \\
$1.2 \mathrm{ml} / \mathrm{min}$ & \\
B: Change in Mobile Phase $\mathbf{\pm \mathbf { 5 } \% )}$ & $0.28 \%$ \\
Buffer: ACN $(55: 45) \mathrm{v} / \mathrm{v}$ & $0.12 \%$ \\
Buffer: ACN $(50: 50) \mathrm{v} / \mathrm{v}$ & $0.07 \%$ \\
Buffer: ACN $(45: 55) \mathrm{v} / \mathrm{v}$ & \\
C: Change in wavelength $\mathbf{( \pm 2} \mathbf{~ n m})$ & $0.34 \%$ \\
$208 \mathrm{~nm}$ & $0.12 \%$ \\
$210 \mathrm{~nm}$ & $0.22 \%$ \\
$212 \mathrm{~nm}$ & \\
\hline
\end{tabular}

Table 6: Specificity study for dimethyl fumarate

\begin{tabular}{|c|c|c|c|c|}
\hline & Component & Retention time (min) & Purity angle & Purity threshold \\
\hline Blank & Dimethyl fumarate & No & --- & --- \\
\hline Dimethyl fumarate standard & Dimethyl fumarate & 3.436 & 0.190 & 0.268 \\
\hline Identification solution Fumaric acid & Fumaric acid & 1.637 & 6.709 & 14.58 \\
\hline Identification solution monomethyl Fumarate & Monomethyl fumarate & 2.078 & 0.841 & 1.156 \\
\hline Sample $240 \mathrm{mg}$ & Dimethyl fumarate & 3.432 & 0.199 & 0.273 \\
\hline \multirow[t]{3}{*}{ Spiked sample $240 \mathrm{mg}$} & Dimethyl fumarate & 3.436 & 0.121 & 10.084 \\
\hline & Fumaric acid & 1.645 & 10.520 & 12.774 \\
\hline & Monomethyl fumarate & 2.079 & 2.993 & 13.818 \\
\hline
\end{tabular}

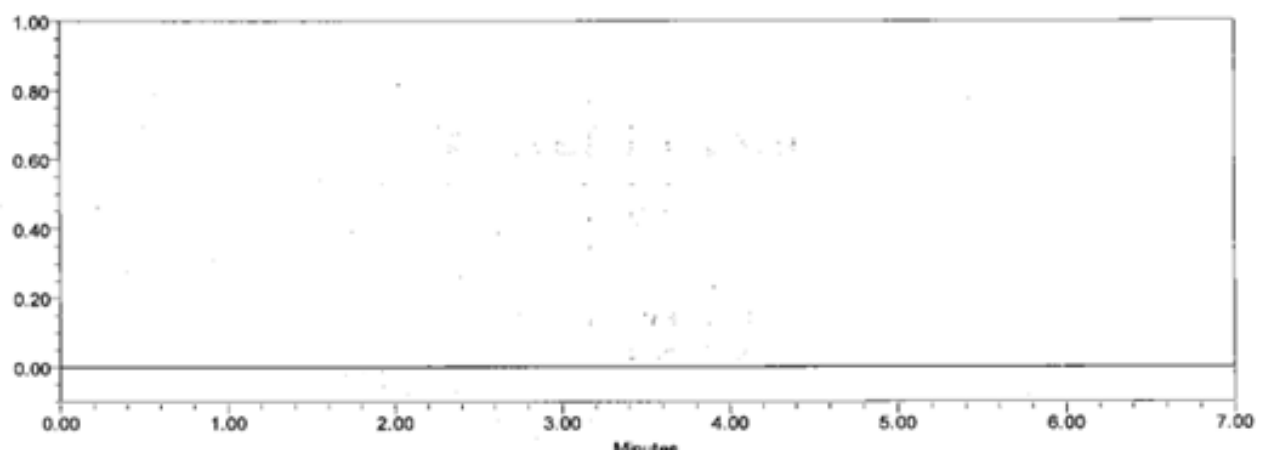

Fig. 4 (a): Chromatogram of blank solution

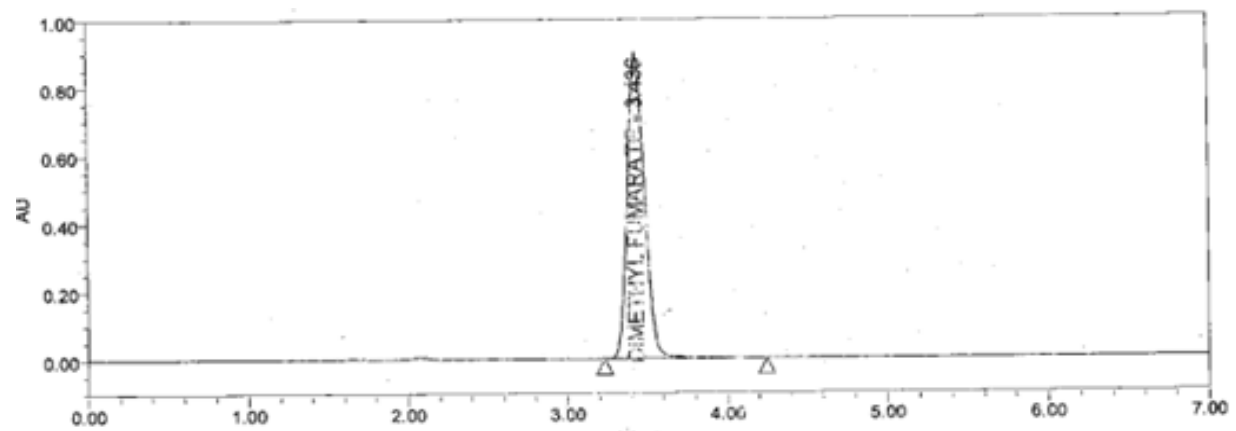

Fig. 4 (b): Chromatogram of standard solution 


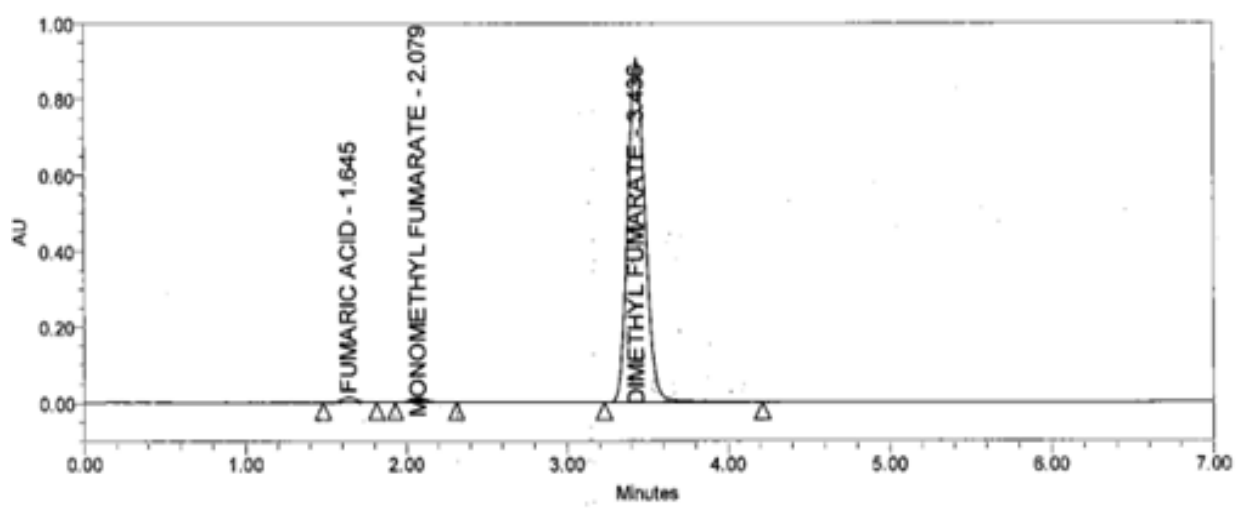

Fig. 3: (c). Chromatogram of spiked sample

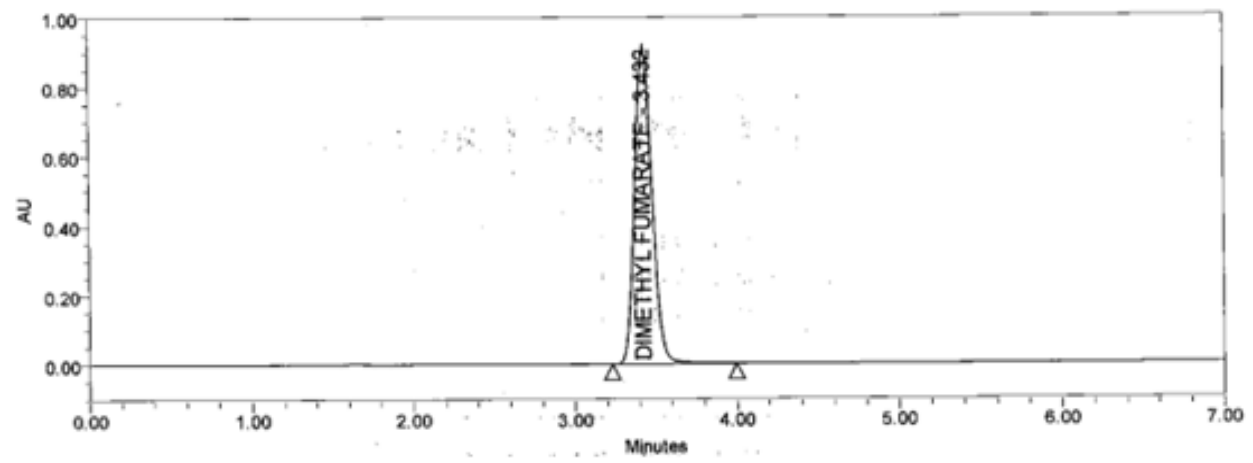

Fig. 5(a)

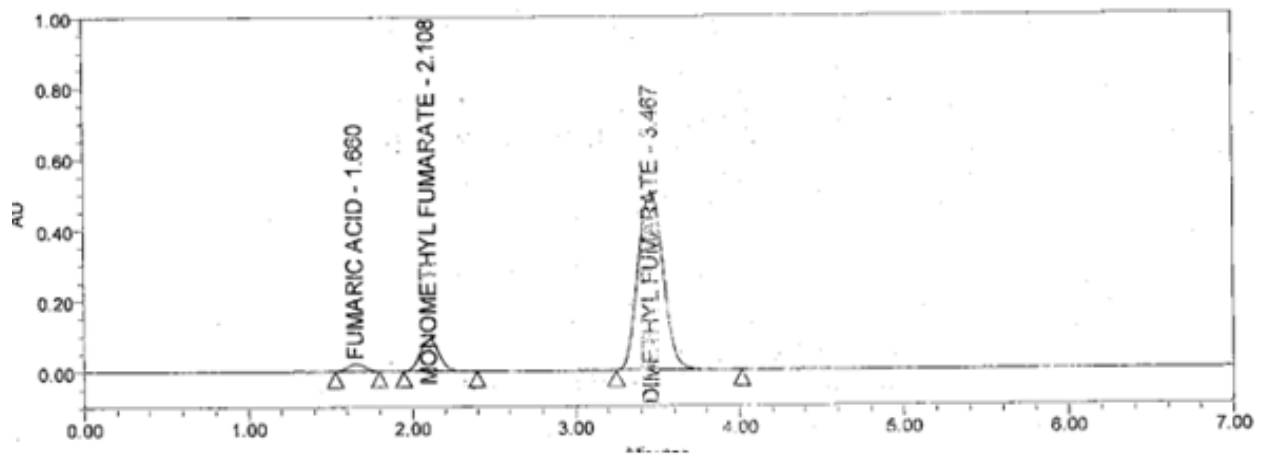

Fig. 5(b)

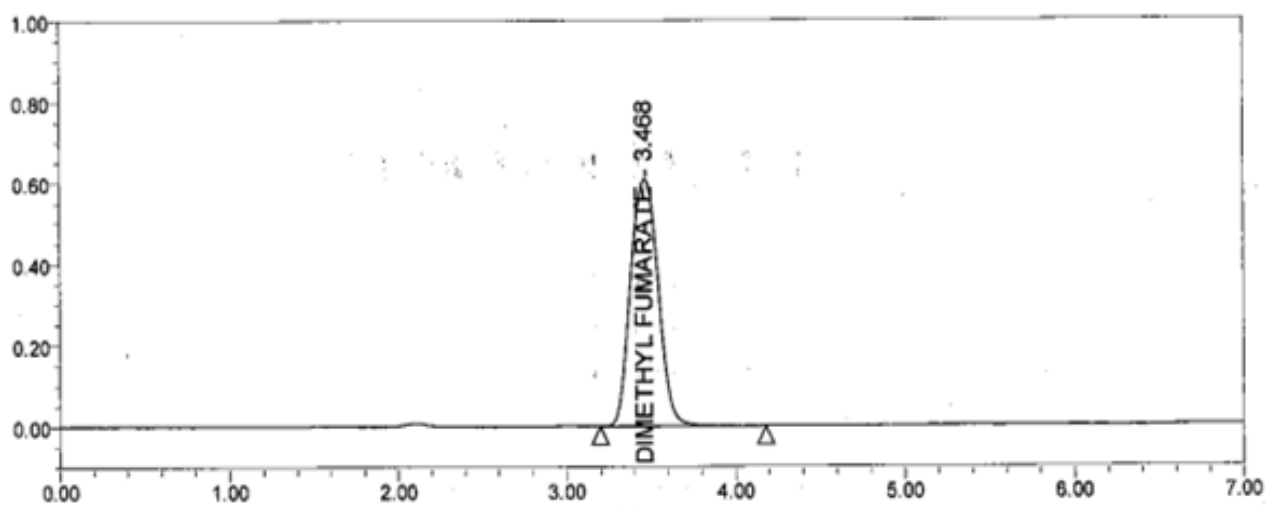

Fig. 5(c) 


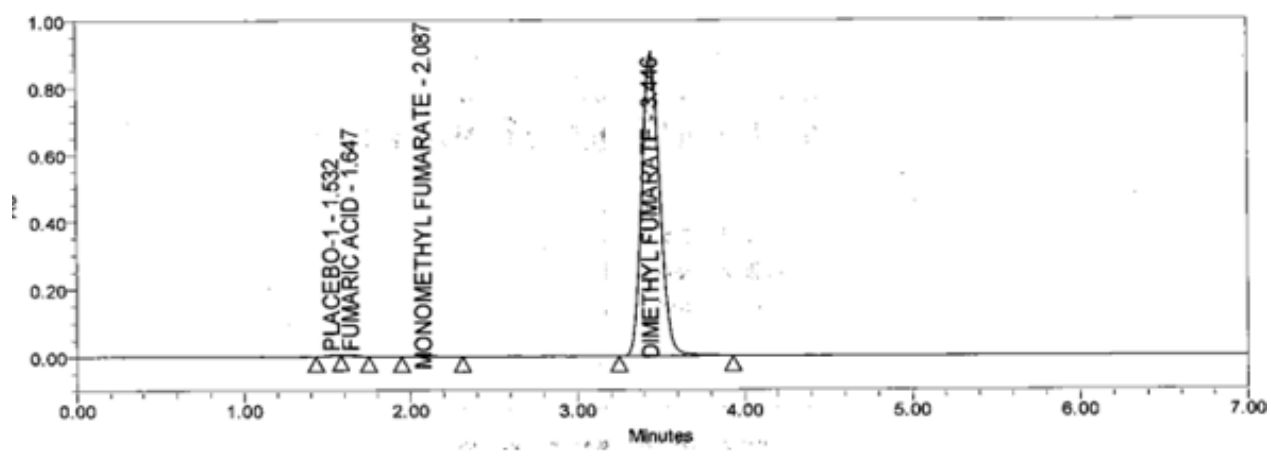

Fig. 5(d)

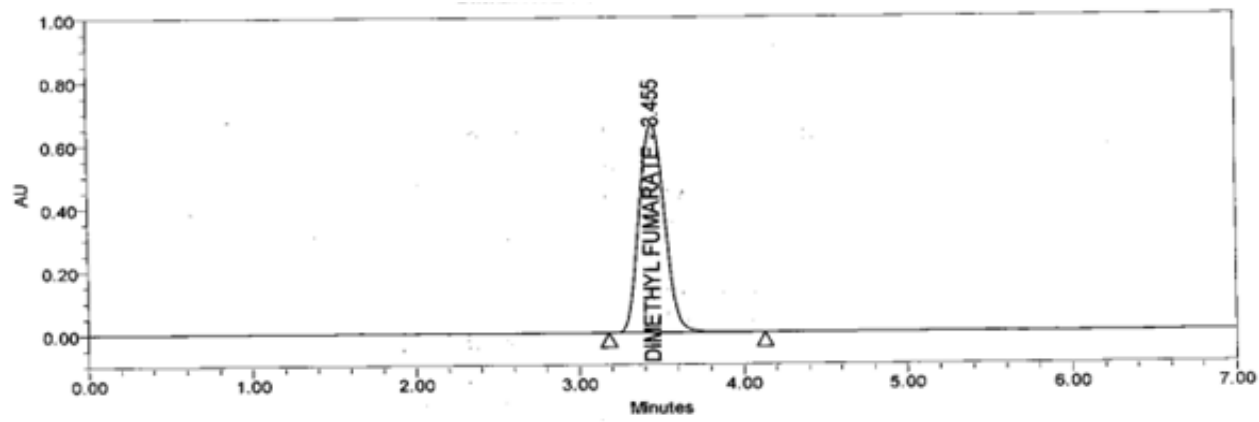

Fig. 5(e)

Fig. 5: Typically degradation chromatograms of dimethyl fumarate; (a) in control sample; (b) in $0.1 \mathrm{~N} \mathrm{HCl}$ at $80{ }^{\circ} \mathrm{C}$ after $1 \mathrm{~h}$; (c) in $0.1 \mathrm{~N}$ $\mathrm{NaOH}$ at $80{ }^{\circ} \mathrm{C}$ after $1 \mathrm{~h}$; (d) in $3 \% \mathrm{H}_{2} \mathrm{O}_{2}$ at $80^{\circ} \mathrm{C}$ after $1 \mathrm{~h}$; (e) in thermal degradation at $105{ }^{\circ} \mathrm{C}$ after $1 \mathrm{~h}$

The first chromatogram obtained by control sample [fig. 4(a)] was used for degradation of dimethyl fumarate but there was no degradation. Second chromatogram obtained by acid hydrolysis [fig. 4 (b)] suggested that $14.7 \%$ degradation of the drug was found, when refluxed at $80^{\circ} \mathrm{C}$ for $1 \mathrm{~h}$ in $0.1 \mathrm{~N} \mathrm{HCl}$. The major degradation product formed was at $3.467 \mathrm{~min}$ retention time. This study indicates that dimethyl fumarate was not stable to acid hydrolysis. Third chromatogram obtained by alkaline hydrolysis [fig. 4(c)] indicated that dimethyl fumarate was stable to alkaline hydrolysis when refluxed at $80{ }^{\circ} \mathrm{C}$ for $1 \mathrm{~h}$ in $0.1 \mathrm{~N} \mathrm{NaOH}$. The Value of \% degradation was found to be $0.3 \%$ and major degradation products appeared at 3.46 min retention time. Fourth chromatogram obtained by oxidative degradation [fig. 4 (d)] suggested that $1.18 \%$ degradation was observed when refluxed with $3 \% \mathrm{H}_{2} \mathrm{O}_{2}$ at $80{ }^{\circ} \mathrm{C}$ for $1 \mathrm{~h}$. The major degradation products appeared at 3.44 min retention time. Fifth chromatogram obtained by thermal degradation [fig. 4(e)] suggested that $0.1 \%$ degradation was observed indicating that dimethyl fumarate is stable when refluxed at $105^{\circ} \mathrm{C}$ for $1 \mathrm{~h}$. The major degradation product was obtained at $3.45 \mathrm{~min}$ retention time.

\section{Stability of analytical solution}

The stability data obtained is summarized in table 7. The values of \% RSD of standard and sample solution were found within acceptance criteria.

\section{Filter compatibility study}

Percent RSD of unfiltered and filtered standard solutions, as well as sample solutions (table 8), is found within the limit. Hence, these filters are compatible.

Table 7: Stability of analytical solutions

\begin{tabular}{llll}
\hline & Initial & Bench top(46 h) & $\mathbf{1 5}^{\circ} \mathbf{C}(\mathbf{4 6} \mathbf{~ h})$ \\
\hline Standard solution \% RSD & 0.11 & 1.08 & 0.96 \\
Sample solution \% RSD & 0.14 & 0.67 & 1.24 \\
\hline
\end{tabular}

Table 8: Filter compatibility study of standard and sample

\begin{tabular}{lll}
\hline Filter & Standard (\%RSD) & Sample (\%RSD) \\
\hline Unfiltered & 0.56 & Centrifuge (0.44) \\
$0.45 \mu$ Nylon Filter & 1.02 & 0.40 \\
$0.45 \mu$ PVDF Filter & 0.80 & 0.39 \\
$0.45 \mu$ PTFE Filter & 0.27 & 1.65 \\
\hline
\end{tabular}

Results of method validation parameters, forced degradation, the stability of analytical solution and filter compatibility studies were found within acceptance criteria.

\section{CONCLUSION}

The present study represents the first report for stability-indicating HPLC assay for estimation of dimethyl fumarate in bulk and capsules. The method was successfully validated as per ICH guidelines. Results of stress testing study revealed that the method is stability indicating. It can be concluded from the results that the developed method is simple, rapid, accurate, specific and precise. Thus, this method can be used for routine analysis of dimethyl fumarate API and to check the stability of capsules dosage forms. 


\section{ACKNOWLEDGEMENT}

Authors are grateful to Dr. N. S. Kannan, GM, ADL, Enaltec Research Centre, Ambernath and Principal, Sinhgad College of Pharmacy, Pune for providing necessary facilities to complete this project.

\section{CONFLICT OF INTERESTS}

Declared none

\section{REFERENCES}

1. Drugbank. Available from; https://www.drugbank.ca/drugs/ DB08908). [Last accessed on 18 ${ }^{\text {th }}$ Mar 2017]

2. Patient information, Techfidera, Highlights of prescribing information, Biogen Inc, Cambridge [Approved by the U. S. Food and Drug Administration, Revised: 1/2017].

3. Balaji J, Shri CN. Development and validation of RP-HPLC method for determination of related substances of dimethyl fumarate drug product. Indian J Res 2016;5:196-8.

4. Gennari O, Montesano D, Salzano A, Albrizio S, Grumetto L. Determination of dimethyl fumarate in desiccant and anti mould sachets by reversed-phase liquid chromatography. Biom J Res Chromatography 2011;25:1315-8.

5. Suneetha A. Role of dimethyl fumarate in oxidative stress of multiple sclerosis: a review. J Chromatogr Biomed Appl 2016;19:1-6.

6. Suneetha A, Rajeswari RK. Prescriptive oriented drug analysis of multiple sclerosis diseases by LC-UV in whole human blood. J Chromatographic Sci 2016;54:1-10.
7. Suneetha A, Raja K. Comparison of LC-UV and LC-MS methods for simultaneous determination of teriflunomide, dimethyl fumarate and fampridine in human plasma: application to rat pharmacokinetic study. Biomedical J Res Chromatography 2016;1:1-7.

8. ICH Harmonized-Tripartite Guidelines. Validation of Analytical Procedure: Text and Methodology. November Q2(R1); 2005.

9. ICH Harmonized-Tripartite Guidelines. Stability Testing of New Drug Substance And Products. February Q1A(R2); 2003.

10. Supriya C, Ramanjulu N, Venkatasubba N. Validated stabilityindicating assay method for azathioprine in the pharmaceutical dosage form according to ICH guidelines. Int J Pharm Pharm Sci 2014;6:301-7.

11. Pratibha V, Varsha N, Soni MA. Stability indicating HPLC method for the determination if metronidazole using ecofriendly solvent as mobile phase component. Int J Pharm Pharm Sci 2013;5:496-501.

12. Jain HK, Randhe VA. Stability indicating assay method for estimation of midodrine hydrochloride in bulk and tablets. Int J Pharm Pharm Sci 2016:8:283-7.

13. Radhika S, Ragin S. Stability indicating RP-HPLC method for simultaneous estimation of dosulepin hydrochloride and methylcobalamin in tablet dosage form. Int J Applied Pharm Sci 2017;9:69-75.

14. Blessy M, Rachi P, Prajapati N. Development of forced degradation and stability indicating studies of drugs-a review. J Pharm Anal 2014;4:159-65. 